\title{
Response of Western North Dakota Mixed Prairie to Intensive Clipping and Five Stages of Development
}

\author{
CHARLES A. HOLDERMAN AND HAROLD GOETZ
}

\begin{abstract}
The effects of clipping to a $2.54 \mathrm{~cm}$ (1 inch) height at 5 stages of development of western North Dakota mixed prairie were investigated. Soil moisture content at the beginning of the growing season had a greater effect on yields than did the clipping treatments. Observations from this two-year study indicate that soil moisture removal was not affected by the clipping treatments. Clipping significantly affected peak yields by needle-and-threadgrass (Stipa comata) and the Carex species during 1977; and the miscellaneous grasses (Agropyron smithii and Agropyron subsecundum) during 1978 , at the sandy loam site. No significant differences in yields were observed for the other species and groups at the sandy loam site, or, the species and groups at the loam site for the two-yearperiod.
\end{abstract}

Late season livestock gains in western North Dakota may be improved if the amount of blue grama (Bouteloua gracilis), the dominant palatable warm-season shortgrass, could be increased without decreasing the overall productivity of the range. Whitman (1953) reported that normal grazing usage results in a cover which is probably of greater grazing value than the completely protected cover. Employing a deferred and rotation system, Sarvis (1923) reported greater total gains on fewer acres when compared to a continuous grazing system. Under the deferred and rotation system, the vegetation was allowed to mature periodically before being subjected to grazing again. A new system of ranching, referred to as the Short Duration Grazing or SDG system, was developed in Rhodesia in 1964 (Goodloe 1969). This system consists of a high intensity-low frequency harvesting of the forage, even with intensive harvesting range conditions improved under the semiarid climate where the SDG system was developed. The present study was designed to determine the effect of intensive harvesting on the developmental stages of Northern Great Plains mixed prairie.

Clipping results in more severe injury to grass stands than does defoliation from normal grazing use (Whitman et al. 1961). Although clipping does not directly duplicate the effects of grazing, considerable information may be gained by the reactions of species to foliage removal (Sarvis 1923).

The effects of clipping on the Northern Great Plains have been reported by different authors. In South Dakota, Black et al. (1937) reported that frequency of clipping buffalo grass (Buchloe dactyloides) and blue grama appeared to have little effect on yield. Total production of buffalo grass, blue grama, western wheatgrass (Agropyron smithii), plains bluegrass (Poa arida), and six weeks fescue (Festuca octoflora) was greatest when clipped at 40-day intervals. Total production by all plants was also greatest when clipped at 40-day intervals. Two vegetation types in western North

At the time of the research, authors were graduate student and chairman, Botany Department, North Dakota State University, Fargo, 58105. Holderman's present address is Ozark Francis National Forests, P.O. Box 1008, Russellville, Arkansas 72801 .

This report is a contribution of North Dakota Agricultural Experiment Station. Published with approval of the Director as Journal Paper No. 1091

Manuscript received October 19, 1979.
Dakota, a western wheatgrass-blue grama type, and a needle-andthreadgrass (Stipa comata)-blue grama-sedge (Carex spp.) type were studied by Whitman and Helgeson (1946). Average yields for blue grama decreased in both vegetation types when clipped twice during a season to a height of $1.27 \mathrm{~cm}(1 / 2 \mathrm{in})$. Needle-andthreadgrass decreased under all clipping treatments in height, yield, and basal area. Average yields for western wheatgrass were maintained under single clipping to a height of $3.81 \mathrm{~cm}(11 / 2$ in $)$ and $7.62 \mathrm{~cm} \mathrm{(3} \mathrm{in),} \mathrm{but} \mathrm{decreased} \mathrm{under} \mathrm{double} \mathrm{clipping.} \mathrm{Sarvis}$ (1923) reported blue grama was benefited by frequent clipping while needle-and-threadgrass decreased in relation to clipping frequency. Heinrichs and Clark (1961) in Saskatchewan, and Whitman et al. (1961) at Dickinson, North Dakota, reported that yields of green needlegrass (Stipa viridula) increased when clipped 2 or 3 times a year compared to annual clipping.

These studies applied periodic and/or annual clipping treatments. The present paper reports the response of Northern Great Plains mixed prairie to intensive clipping at five stages of development, with respect to peak yields and basal cover of selected species and groups, and the seasonal removal of soil moisture in the profile.

\section{Description of Study Locations}

This study was carried out on two major range sites in western North Dakota. Vegetation of the region is mixed grass prairie as described by Weaver and Clements (1938). Study site 1 is located approximately $9.6 \mathrm{~km}$ (6 miles) northwest of the city of Dickinson on a sandy loam of the Vebar-Parshall-Arnegard toposequence (Larson et al. 1968). Dominant perennial grasses a re needle-andthreadgrass, green needlegrass, blue grama, prairie Junegrass (Koeleria cristata), and Sandberg bluegrass (Poa secunda). The miscellaneous grasses are dominated by western wheatgrass and bearded wheatgrass (Agropyron subsecundum). Major Carex species are C. filifolia, C. eleocharis, and C. heliophila. Study site 2 is located approximately $14.4 \mathrm{~km}$ (9 miles) southeast of the town of Medora on a loam soil similar to the Shambo series (U.S. Dep. Agr. Forest Serv. 1971; and personal communication with Ken Thompson, Soil Conserv. Serv., Dickinson, N.D.). Dominant perennial grasses are western wheatgrass, blue grama, prairie Junegrass, and needle-and-threadgrass. The miscellaneous grasses are dominated by green needlegrass (Stipa viridula) and Sandberg bluegrass (Poa secunda). Major Carex species are C. filifolia, C. eleocharis, and C. heliophila. Scientific and common names follow Stevens (1963). Abbreviated scientific names follow the Range Analysis Handbook U.S.F.S. (1977).

The climate of the region is semiarid with an annual precipitation between $40.13 \mathrm{~cm}$ (15.80 inches) and $42.06 \mathrm{~cm}$ (16.56 in), 75\% of which falls during the growing season April through September.

\section{Experimental Procedures}

The experimental plots were randomly located with three repli- 
cates of eight treatments on each of two study sites. Plot size was

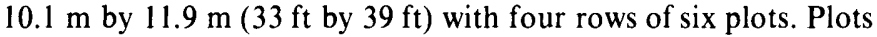
were subdivided into six $3.96 \mathrm{~m}$ by $5.03 \mathrm{~m}$ ( $13 \mathrm{ft}$ by $16.5 \mathrm{ft}$ ) subplots, half of which were randomly selected to be sampled for above ground biomass in alternating years. Six-foot alley ways were left between plots to facilitate movement. Five of the treatments were clipping trials, two were herbicide trials, and one the control which received no treatment. This paper reports only the results of the clipping trials.

Three plots (replications) on each of the two study sites were mowed to a $2.54 \mathrm{~cm}(1 \mathrm{in})$ height on each of the treatment dates. Clipping (mowing) dates for 1977 were: May 24 and 25; June 9 and 10; June 22 and 23; July 6 and 7; and July 19 and 20, for sites 1 and 2, respectively. Clipping dates for 1978 were: May 20 and 21; June 7 and 8; June 22 and 21 ; July 7 and 6; and July 21 and 19, for sites 1 and 2, respectively. Plots received only one clipping treatment per year. Plots clipped in 1977 were clipped at approximately the same time period in 1978. The clipped herbage was removed following the treatment. Prior to each treatment three subplots from each replication were randomly sampled for above ground biomass using one $1 / 8-\mathrm{m}^{2}(25 \mathrm{~cm}$ by $50 \mathrm{~cm})$ quadrat for a total of nine $1 / 8-\mathrm{m}^{2}$ quadrats per treatment. Control plots were sampled for biomass at approximate biweekly intervals from mid May through mid July and a terminal harvest in mid October 1977 and early September 1978. The May clip, first Junc clip, and the second June clip were sampled for regrowth at approximate monthly intervals until mid to late July and during mid October of 1977 and early September of 1978 . Nine $1 / 8-\mathrm{m}^{2}$ quadrats were randomly located for the regrowth sampling. Species composition by weight was estimated using the double sampling technique. The double sampling technique consisted of estimating the percent by weight of species composition, and then clipping by species the first and last quadrats of the 9 quadrats clipped for the biomass samples. The percent by weight of species composition was estimated for quadrats 2 through 8 and the clipped herbage combined for the quadrat sample. Clipped herbage was then dried at $66^{\circ} \mathrm{C}$ for 72 hours and weighed to the nearest 0.1 gram. Correction percentages from quadrats 1 and 9 were applied to quadrats 2 through 8 . Peak yields for the clipping treatments were determined from adding the biomass samples taken prior to the clipping treatment with each of the samples taken for regrowth. Peak yield reported is the maximum cumulative average yield per treatment for the selected species and groups. Peak yields on control plots were the biomass peaks for the selected species and groups.

Soil moisture content was determined utilizing the gravimetric method in 1977 and the neutron-scattering method in 1978. Sampling depths for 1977 were: $1-15 \mathrm{~cm}, 15-30 \mathrm{~cm}, 30-45 \mathrm{~cm}, 45-60$, $60-75 \mathrm{~cm}, 75-90 \mathrm{~cm}$, and $90-120 \mathrm{~cm}$. Sampling depths for 1978 were: $0-15 \mathrm{~cm}, 15-30 \mathrm{~cm}, 30-45 \mathrm{~cm}, 45-60 \mathrm{~cm}, 60-75 \mathrm{~cm}$, and $75-105 \mathrm{~cm}$. (A $15-\mathrm{cm}$ error in lowering the probe's source resulted in the change of sampling depths in 1978). The gravimetric method was utilized for the $0-15 \mathrm{~cm}$ depth in 1978. Gravimetric samples were dried at $105^{\circ} \mathrm{C}$ for 72 hours and weighed to the nearest 0.1 gram. The soil moisture content was sampled at biweekly intervals from approximately May 15 through August 15. The amount of soil water removed was determined utilizing a method described by Neff and Wight (1977). They reported: "The available soil water is the difference between the soil water measurement and the minimum soil water measured at anytime during the period of record. This definition assumed that the minimum soil water measured during the period of record approximated the soil water holding capacity at wilting point". Their definition of available soil water was interp retated to be the amount of soil water removed through evapotranspiration. Soil moisture removed for 1977 is reported for the period of June 7 through August 11; and for 1978 the period of May 15 through August 24.

Basal cover was determined in August of 1977 and 1978 using the point contact method. A hit was recorded when the point came into contact with the base of a living (green) plant. Percent basal cover was determined from 3,600 points per treatment. According to
Whitman and Siggeirsson (1954) 3,600 basal contact points would provide sampling errors of $10 \%$ or less for the three major components-needle-and-threadgrass, blue grama, and the sedges; and sampling errors between 10 and $20 \%$ for all other species and groups, except for plains reedgrass (Calamagrostis montanensis).

Data were analyzed using standard analysis of variance techniques. The Duncan's multiple range test was used to separate mean differences when significant $(P<0.10$ or $P<0.05)$ values were found. $\Lambda$ cceptance levels for significant differences reported are at the $P<0.05$ level unless otherwise stated to be at the $P<0.10$ level.

\section{Results and Discussion}

\section{Above-ground Biomass}

Clipping to a $2.54 \mathrm{~cm}(1 \mathrm{in})$ height on May 24 and June 10 reduced $(P<0.10)$ yields of needle-and-threadgrass compared to yields observed for the $2.54-\mathrm{cm}(1 \mathrm{in})$ clipping in July 19 and control plots during 1977 at site 1 (Fig. 1). Needle-and-threadgrass yields were not significantly different between the control plots, June 22, July 7, and July 19 clipping treatments; or between the May 24, June 10, June 22, and July 7 clipping treatments. Yields by Carex species increased $(P<0.10)$ when clipped to a $2.54 \mathrm{~cm}(\mathrm{I}$ in) height on June 10 compared to yields on control plots, May 24, and July $192.54 \mathrm{~cm}$ ( 1 in) clipping treatments. When clipped to a 2.54 $\mathrm{cm}(1 \mathrm{in})$ height on July 7, yields by Carex species increased $(P<0.10)$ above yields observed for the control plots and the July 19 2.54-cm ( 1 in) clipping treatment. No significant differences in yield of Carex species were observed for: the May 24, June 22, and July $72.54 \mathrm{~cm}$ (1 in) clipping treatments. Clipping did not significantly affect yields by green needlegrass, prairie Junegrass, blue grama, Sandberg bluegrass, miscellaneous grasses, or the forbs for 1977. The June 22 clipping treatments increased $(R<0.10)$ the peak yield compared to the May 24 clipping treatment and control plots (Fig. 2). Clipping did not significantly affect peak yields between: the June 10, June 22, July 7, and July $192.54 \mathrm{~cm}$ (1 in) clips; or the control plots, May 24, and July $192.54 \mathrm{~cm}$ (1 in) clipping treatments. Peak yields were increased $(P<0.10)$ by the June 10 , June 22 , and July $72.54 \mathrm{~cm}$ (1 in) clipping treatments above those observed on May 24 clipping treatment and control plots for 1977. Observation indicated an increase $(P<0.10)$ in yield by the miscellaneous grasses when clipped to a $2.54 \mathrm{~cm}$ ( 1 in) height on July 21 as compared to all other $2.54-\mathrm{cm}$ ( 1 in) clipping treatments and control plots for the 1978 growing season (Fig. 1). Clipping did not significantly reduce yields by needle-and-threadgrass and prairie Junegrass in 1978. No significant differences in yield were observed for the other species and groups, or the peak yields at site 1 for the 1978 growing season (Fig. 1 and Fig. 2, respectively). Clipping did not affect yields during the 1977 or 1978 growing seasons at site 2 (Fig. 1 and Fig. 2).

The relationship between soil moisture and forage yields was observed at both sites during this two-year study period (Fig. 1 and Fig. 2). These observations agree with studies reported by Rogler and Haas (1947) working near Mandan, North Dakota. They reported that when soil moisture was above or below average, forage yields showed a positive relationship of being above or below average. The dry conditions observed at the beginning of the 1977 growing season, when compared to 1978, appeared to have a greater effect on yields than the clipping treatments. However, early season clipping appeared to have compounded the effects of dry conditions on needle-and-threadgrass by reducing yields at site 1 during 1977 (Fig. 1). Precipitation for the period of January through May of 1977 was $12 \%$ below normal at Dickinson and Medora (Table 1). For the same time period in 1978, precipitation was $18.7 \%$ of $51.2 \%$ above normal at Dickinson and Medora, respectively. The growing season precipitation, April through September, was above normal at both stations during 1977 and 1978. Even with above-average growing season precipitation during both years, forage yields were higher in 1978 as a result of higher soil moisture levels at the beginning of the growing season when 
Table 2. Average percent basal cover of selected species and groups in August of 1977 and 1978, for each of the 5 clipping treatments and control plots at site 1.

\begin{tabular}{|c|c|c|c|c|c|c|c|c|c|c|c|c|}
\hline \multirow[b]{2}{*}{ Species } & \multicolumn{6}{|c|}{1977} & \multicolumn{6}{|c|}{1978} \\
\hline & May 24 & June 10 & June 22 & July 6 & July 19 & Control & May 20 & June 7 & June 22 & July 7 & July 21 & Control \\
\hline $\begin{array}{l}\text { Stipa viridula } \\
\text { (Green needlegrass) }\end{array}$ & 3.50 & 1.06 & 0.66 & 0.97 & 0.93 & 0.23 & 0.63 & 1.37 & 0.17 & 0.70 & 0.70 & \\
\hline $\begin{array}{l}\text { Stipa comata } \\
\text { (Needle-and-thread- } \\
\text { grass) }\end{array}$ & 0.73 & 0.90 & 1.37 & 0.93 & 1.50 & 1.83 & 1.43 & 0.97 & 1.17 & 0.73 & 1.13 & 2.17 \\
\hline $\begin{array}{l}\text { Koeleria cristata } \\
\quad \text { (Prairie Junegrass) }\end{array}$ & 1.17 & 1.17 & 1.67 & 0.63 & 0.47 & 0.93 & 1.83 & 1.73 & 1.70 & 0.90 & 1.70 & 2.43 \\
\hline $\begin{array}{l}\text { Bouteloua gracilis } \\
\text { (Blue grama) }\end{array}$ & 2.37 & 3.00 & 2.60 & 2.07 & 2.17 & 2.33 & $4.33 \mathrm{a}^{1}$ & $3.77 \mathrm{ab}$ & $3.70 \mathrm{abc}$ & $2.53 \mathrm{bc}$ & $2.27 \mathrm{c}$ & $2.37 \mathrm{bc}$ \\
\hline $\begin{array}{l}\text { Poa secunda } \\
\quad \text { (Sand berg bluegrass) }\end{array}$ & $0.37 a b^{2}$ & $0.70 \mathrm{a}$ & $0.16 \mathrm{~b}$ & $0.07 b$ & $0.06 \mathrm{~b}$ & $0.67 \mathrm{a}$ & $0.15 \mathrm{~b}^{1}$ & $0.57 \mathrm{~b}$ & $0.16 \mathrm{~b}$ & $0.20 \mathrm{~b}$ & $0.15 b$ & $1.17 \mathrm{a}$ \\
\hline Misc. grasses & 0.37 & 0.23 & 0.27 & 0.12 & 0.09 & 0.13 & 0.77 & 0.57 & 0.33 & 0.50 & 0.40 & 0.29 \\
\hline $\begin{array}{l}\text { Carex spp. } \\
\text { (Sedges) }\end{array}$ & $1.18 \mathrm{c}^{1}$ & $2.57 \mathrm{cb}$ & $1.57 \mathrm{c}$ & $3.13 \mathrm{ab}$ & $3.73 \mathrm{a}$ & $2.50 \mathrm{cb}$ & 1.70 & 2.40 & 1.30 & 2.47 & 1.83 & 2.03 \\
\hline Forbs & 0.40 & 0.37 & 0.40 & 0.19 & 0.16 & 0.05 & 0.05 & 0.16 & 0.12 & 0.37 & 0.13 & 0.19 \\
\hline $\begin{array}{l}\text { Selaginella densa } \\
\quad \text { (Small clubmoss) }\end{array}$ & 2.10 & 0.90 & 3.80 & 1.10 & 0.80 & 4.80 & 4.30 & 2.10 & 5.60 & 1.80 & 1.20 & 4.70 \\
\hline Total* & $7.90 \mathrm{~b}^{1}$ & $9.90 \mathrm{a}$ & $8.33 b$ & $8.03 b$ & $9.10 \mathrm{ab}$ & $8.40 \mathrm{~b}$ & $10.87 \mathrm{a}^{1}$ & $11.43 \mathrm{a}$ & $8.77 \mathrm{~b}$ & $7.87 \mathrm{~b}$ & $8.20 b$ & $11.27 \mathrm{a}$ \\
\hline
\end{tabular}

* Total basal cover values excluding Selaginella densa.

'Means in the same row followed by similar letters are not significantly different at the 0.05 level of probability.

${ }^{2}$ Means in the same row followed by similar letters are not significantly different at the 0.10 level of probability.

compared to the control plots, the May 20, and June 7 clipping treatments. The May 20 clipping treatment increased the basal cover of blue grama during 1978 above that observed for the control plots, July 7 , and July 21 clipping treatments. Even though the basal cover of Sandberg bluegrass decreased on the clipping treatments and a general increase in basal cover of blue grama was observed for the May 20, June 7, and June 22 clipping treatments during 1978, clipping did not significantly affect yields by either species (Fig. 1).

Prairie Junegrass decreased $(P<0.10)$ in basal cover when clipped to a $2.54 \mathrm{~cm}$ ( 1 in) height on July 20 compared to the control plots, the May 25, and June 9 clipping treatments at site 2 for 1977 (Table 3). The June 23 clipping treatment reduced $(P<0.10)$ the basal cover of prairie Junegrass compared to the May 24 clipping treatment and control plots. Prairie Junegrass made very little regrowth following the June 23 , July 7 , and July 20 clipping treatments during 1977. It was difficult to distinguish between living (green) plants and dead plants when the point contact method was used in August, resulting in the lower number of hits observed. The difficulty in distinguishing between living and dead plants, rather than the clipping treatments, may have accounted for the decrease in basal cover in 1977. Clipping did not affect the basal cover for prairie Junegrass in 1978. The clipping treatments did not affect the basal cover of the other species and groups, or the total basal cover, when excluding small clubmoss, on site 2 for the two-year period.

\section{Soil Moisture}

The soil moisture content at the beginning of the growing season greatly influenced forage production. Dickinson received $9.40 \mathrm{~cm}$ of precipitation from October 1976 through April 1977, 18.1\% below normal. Precipitation for the same time period in 1977 and 1978 was $56.4 \%$ above normal (Table 1). During mid May 1977, the average percent soil moisture on the control plots at site 1 was $4.4 \%$ and $19.7 \%$ at mid May 1978 . Medora, a measuring station within $14.4 \mathrm{~km}$ of site 2, received $6.76 \mathrm{~cm}$ of precipitation from October 1976 through April 1977, or 36.5\% below normal. Precipitation for the same time period in 1977 and 1978 was $23.2 \%$ above normal

Table 3. Average percent basal cover of selected species and groups in August of 1977 and 1978, for each of the 5 clipping treatments and control plots at site 2.

\begin{tabular}{|c|c|c|c|c|c|c|c|c|c|c|c|c|}
\hline \multirow[b]{2}{*}{ Species } & \multicolumn{6}{|c|}{1977} & \multicolumn{6}{|c|}{1978} \\
\hline & May 25 & June 9 & June 23 & July 7 & July 20 & Control & May 21 & June 8 & June 21 & July 6 & July 19 & Control \\
\hline $\begin{array}{l}\text { Agropyron smithii } \\
\text { (Western wheatgrass) }\end{array}$ & 1.50 & 1.40 & 1.60 & 1.07 & 0.80 & 1.07 & 0.87 & 1.40 & 1.17 & 1.17 & 1.00 & 0.63 \\
\hline $\begin{array}{l}\text { Stipa comata } \\
\text { (Needle-and-thread- } \\
\text { grass) }\end{array}$ & 0.10 & 0.26 & 0.26 & 0.40 & 0.50 & 0.40 & 0.27 & 0.20 & 0.13 & 0.13 & 0.23 & 0.33 \\
\hline Koeleria cristata & $1.07 \mathrm{a}^{1}$ & $0.87 \mathrm{ab}$ & $0.30 \mathrm{bc}$ & $0.43 a b c$ & $0.13 \mathrm{c}$ & $1.00 \mathrm{a}$ & 1.50 & 1.30 & 0.73 & 0.87 & 1.13 & 1.47 \\
\hline $\begin{array}{l}\text { Bouteloua gracilis } \\
\text { (Blue grama) }\end{array}$ & 3.53 & 3.97 & 4.47 & 4.90 & 5.47 & 5.20 & 5.97 & 5.43 & 4.87 & 4.73 & 5.10 & 5.40 \\
\hline Misc. grasses & 0.0 & 0.0 & 0.02 & 0.0 & 0.0 & 0.0 & 0.23 & 0.03 & 0.05 & 0.09 & 0.0 & 0.17 \\
\hline $\begin{array}{r}\text { Carex spp. } \\
\text { (Sedges) }\end{array}$ & 1.80 & 1.47 & 1.37 & 1.60 & 2.73 & 2.13 & 1.13 & 1.29 & 1.07 & 0.90 & 1.60 & 1.47 \\
\hline Forbs & 0.53 & 0.67 & 0.67 & 0.27 & 0.17 & 0.36 & 0.30 & 0.23 & 0.70 & 0.08 & 0.20 & 0.19 \\
\hline $\begin{array}{l}\text { Selaginella densa } \\
\quad \text { (Small clubmoss) }\end{array}$ & 12.0 & 16.80 & 13.80 & 17.30 & 21.50 & 24.70 & 7.70 & 14.20 & 10.50 & 12.30 & 12.60 & 21.40 \\
\hline Total* & 8.40 & 8.57 & 8.57 & 8.70 & 9.73 & 10.30 & 10.3 & 9.23 & 8.87 & 7.93 & 9.20 & 9.70 \\
\hline
\end{tabular}

*Total basal cover values excluding Selaginella densa.

${ }^{1}$ Means in the same row followed by similar letters are not significantly different at the 0.10 level of probability. 
Table 4. A comparison of the amount $(\mathrm{cm})$ of soil moisture removed for the 5 clipping treatments and control plots at site 1 for the 1977 and 1978 sampling periods.

\begin{tabular}{llllllll}
\hline \hline $\begin{array}{l}\text { Clipping } \\
\text { treatment } \\
\text { date }\end{array}$ & $0-15$ & $15-30$ & $30-45$ & $45-60$ & $60-75$ & $75-90$ & $90-120$ \\
\hline 1977 & & & & & & & \\
$\quad$ May 24 & 3.05 & 2.32 & 1.29 & 0.78 & 1.19 & 0.93 & 1.20 \\
June 10 & 3.52 & 2.55 & 2.24 & 1.07 & 0.77 & 1.06 & 1.06 \\
June 22 & 2.84 & 2.35 & 2.07 & 1.36 & 1.85 & 0.75 & 1.07 \\
July 6 & 3.40 & 2.60 & 2.09 & 1.41 & 1.74 & 1.69 & 1.83 \\
July 19 & 3.04 & 1.94 & 1.74 & 0.96 & 1.25 & 1.11 & 2.13 \\
Control & 2.94 & 2.08 & 1.75 & 1.28 & 1.14 & 0.75 & 0.30 \\
& & & & & & & \\
& $0-15$ & $15-30$ & $30-45$ & $45-60$ & $60-75$ & $75-105$ & \\
\hline 1978 & & & & & & & \\
May 20 & 2.81 & 3.10 & 2.79 & 2.89 & 2.86 & 4.31 & \\
June 7 & 2.83 & 3.51 & 3.13 & 3.12 & 3.05 & 4.31 & \\
June 22 & 3.34 & 3.10 & 2.79 & 2.59 & 2.59 & 3.78 & \\
July 7 & 2.76 & 3.48 & 2.95 & 2.91 & 2.68 & 3.37 & \\
July 21 & 2.79 & 3.22 & 3.03 & 2.91 & 2.95 & 4.06 & \\
Control & 2.15 & 2.76 & 2.71 & 2.60 & 2.59 & 5.05 & \\
\hline
\end{tabular}

(Table 1). During mid May 1977 the average percent soil moisture on the control plots at site 2 was $7.0 \%$ and $25.1 \%$ at mid May 1978 . The higher soil moisture levels at the beginning of the growing season in 1978 resulted in higher forage yields when compared to 1977 (Fig. 1 and 2).

Clipping did not significantly affect soil moisture removal at site 1 during 1977 and 1978 (Table 4). Significant $(P<0.10)$ differences in soil moisture removal were observed at the $30-45 \mathrm{~cm}$ (12 to $18 \mathrm{in})$ depth and $(P<0.05)$ at the $75-90 \mathrm{~cm}$ (30 to $36 \mathrm{in})$ depth during the 1977 sampling period at site 2 (Table 5). The gravimetric method was used for the 1977 sampling period. Spotty natric horizons (claypans) were encountered on some of the treatment replications at site 2 . The differences in soil moisture may be the result of a combination of the "claypan" layers and below normal precipitation at the beginning of the 1977 growing season. A slight recharge in soil moisture was observed in the $75-105 \mathrm{~cm}$ (30 to $42 \mathrm{in}$ ) depth on the control plots and the July $192.54-\mathrm{cm}$ ( 1 in) clipping treatment for the 1978 sampling period at site 2 . Lateral movement of

Table 5. A comparison of the amount $(\mathrm{cm})$ of soil moisture removed for the 5 clipping treatments and control plots at site 2 for the 1977 and 1978 sampling periods.

\begin{tabular}{|c|c|c|c|c|c|c|c|c|}
\hline \multicolumn{9}{|c|}{$\begin{array}{l}\text { Clipping } \\
\text { treatment }\end{array}$} \\
\hline date & $0-15$ & $15-30$ & $30-45$ & $45-60$ & $60-75$ & $75-90$ & \multicolumn{2}{|c|}{$90-120$} \\
\hline \multicolumn{9}{|l|}{1977} \\
\hline May & & 1.92 & 1.82 & $1.19 \mathrm{ab}^{1}$ & 1.33 & 1.24 & $1.44 \mathrm{a}^{2}$ & 2.98 \\
\hline June & & 1.24 & 1.35 & $0.52 b$ & 0.97 & 0.97 & $1.31 \mathrm{a}$ & 2.24 \\
\hline Jun & 23 & 2.30 & 1.36 & $1.16 \mathrm{ab}$ & 1.08 & 1.30 & $1.95 \mathrm{a}$ & 1.88 \\
\hline July & & 1.52 & 1.37 & $0.97 \mathrm{ab}$ & 1.28 & 1.39 & $1.41 \mathrm{a}$ & 1.50 \\
\hline July & & 2.28 & 1.58 & $1.62 \mathrm{a}$ & 1.34 & 1.54 & $0.14 b$ & 2.10 \\
\hline \multirow{2}{*}{\multicolumn{2}{|c|}{ Control }} & 1.78 & 2.10 & $1.50 \mathrm{a}$ & 1.39 & 1.57 & $1.49 \mathrm{a}$ & 2.32 \\
\hline & & $0-15$ & $15-30$ & $30-45$ & $45-60$ & $60-75$ & $75-105$ & \\
\hline
\end{tabular}

1978

$\begin{array}{lllllll}\text { May 21 } & 3.23 & 3.67 & 3.74 & 2.65 & 2.70 & 1.68 \\ \text { June 8 } & 4.31 & 3.71 & 3.73 & 3.12 & 1.97 & 0.64 \\ \text { June 21 } & 4.70 & 4.11 & 4.07 & 3.20 & 2.05 & 0.08 \\ \text { July 6 } & 3.86 & 3.29 & 3.36 & 2.81 & 0.95 & 1.20 \\ \text { July 19 } & 4.20 & 2.49 & 2.40 & 2.13 & 1.31 & -.32 \\ \text { Control } & 4.70 & 4.33 & 3.81 & 3.51 & 2.45 & -.30\end{array}$

'Means in the same column with different letters are significantly different at the 0.10 level of probability.

${ }^{2}$ Means in the same column with different letters are significantly different at the 0.05 level of probability.
Table 6. A comparison (average of all clipping treatments and control plots) of the amount (cm) of soil moisture removed between the $0-45 \mathrm{~cm}$ depth and the $45-105 \mathrm{~cm}$ depth from two western North Dakota mixed prairie study sites for the 1977 and 1978 sampling periods.

\begin{tabular}{lllll}
\hline & \multicolumn{2}{c}{ Site 1 } & & \multicolumn{2}{c}{ Site 2 } \\
\cline { 2 - 3 } \cline { 5 - 5 } Year & $0-45$ & $45-105$ & $0-45$ & $45-105$ \\
\hline 1977 & $7.30 \mathrm{a}^{1}$ & $4.15 \mathrm{~b}$ & 4.60 & 4.94 \\
1978 & $8.88 \mathrm{a}$ & $9.77 \mathrm{~b}$ & $11.29 \mathrm{a}^{1}$ & $5.31 \mathrm{~b}$ \\
\hline
\end{tabular}

'Means in the same row followed by different letters are significantly different at the 0.05 level of probability.

water may have accounted for the recharge. Observations from this 2-year study indicate that soil moisture removal was not affected by the clipping treatments.

Precipitation and soil texture influenced the removal of soil moisture. More moisture was removed in the $0-45 \mathrm{~cm}$ depth compared to the $45-105 \mathrm{~cm}$ depth on the sandy loam soil of site 1 during 1977 (Table 6). During 1978 more moisture was removed from the 45-105 cm depth when compared to the $0-45 \mathrm{~cm}$ depth. The increase in soil moisture removal at the $0-45 \mathrm{~cm}$ depth during 1977 may have resulted from the lack of moisture infiltration to the $45105 \mathrm{~cm}$ depth following the above average growing season precipitation (Table 1). No significant differences in soil moisture removal were observed between the $0-45 \mathrm{~cm}$ depth and the $45-105$ $\mathrm{cm}$ depth on the loam soil of site 2 during 1977 (Table 6). During 1978 , more moisture was removed from the $0-45 \mathrm{~cm}$ depth when compared to the $45-105 \mathrm{~cm}$ depth. Even with the above average growing season precipitation during 1977 , water infiltration may have been reduced on the finer textured loam soil at site 2 as comparcd to the more coarse textured sandy loam soil at site 1 .

\section{Conclusions}

The soil moisture content at the beginning of the growing season greatly influenced forage production. Even with above average growing season precipitation during both years, forage yields were higher in 1978 as a result of higher soil moisture levels at the beginning of the growing season when compared to 1977. Early season soil moisture appeared to have a greater affect on yields than the clipping treatments. However, early season clipping appeared to have compounded the effects of dry conditions on needle-and-threadgrass by reducing yields on the sandy loam site during 1977. Observations from this 2-year study indicate the removal of soil moisture was not affected by the clipping treatments. Precipitation and soil texture had a greater influence on the removal of soil moisture than did the clipping treatments.

The basal cover of Sandberg bluegrass was reduced by all 2.54$\mathrm{cm}(1$ in) clipping treatments on the sandy loam site during 1978. Early season clipping increased the basal cover of blue grama on the sandy loam site during 1978. However, clipping did not significantly affect yields by either species.

Hurtt (1951), working near Miles City, Montana, reported the average drought frequency in the Northern Great Plains at once in 5 years. Drought conditions play a major role in proper range and livestock management. Long-term projections can not be made from two years of study. Further research is needed to determine long-term effects of intensive harvesting on the development of western North Dakota mixed prairie.

\section{Literature Cited}

Black, W.H., A.L. Baker, V.I. Clark, and O.R. Mathews. 1937. Effect of different methods of grazing on native vegetation and gains of steers in Northern Great Plains. U.S. Dep. Agr. Tech. Bull. 547. 18 p.

Goodloe, S. 1969. Short duration grazing in Rhodesia. J. Range Manage. 22:369-373.

Heinrichs, D.H., and K.W. Clark. 1961. Clipping frequency and fertilizer effects on productivity and longevity of five grasses. Can. J. Plant Sci. 41:97-108. 
Hurtt, L.C. 1951. Managing Northern Great Plains cattle ranges to minimize the effects of drought. U.S. Dep. Agr. Circ. 865. 24 p.

Larson, K.E., et. al. 1968. Soil survey of Stark County, North Dakota. U.S. Dep. Agr. Soil Conserv. Ser. 116 p.

Neff, E.L., and J.R. Wright. 1977. Overwinter soil water recharge and herbage production as influenced by contour furrowing on eastern Montana rangelands. J. Range Manage. 30:193-195.

Rogler, G.A., and H.J. Haas. 1947. Range production as related to soil moisture and precipitation on the Northern Great Plains. J. Amer. Soc. Agron. 39:378-389.

Sarvis, J.T. 1923. Effects of different systems and intensities of grazing upon native vegetation at the Northern Great Plains field station. U.S. Dep. Agr. Dep. Bull. 1170. 45 p.

Stevens, O.A. 1963. Handbook of North Dakota plants. N. Dak. Inst. for Regional Studies. North Dakota State Univ., Fargo, N. Dak. 324 p.
U.S. Dept. Agr. Forest Serv. 1971. Soils of the national grasslands, western North Dakota and western South Dakota. Custer National Forest. Region 1. Missoula, Mont. 253 p.

U.S. Dep. Agr. Forest Serv. 1977. R-1 Chapter 300 p. 330-335-2 In: Range Analysis Handbook. FSH 2209.21. Missoula, Mont.

Weaver, J.E., and F.E. Clements. 1938. Plant Ecology. McGraw-Hill, New York. 601 p.

Whitman, W.C., and E.A. Helgeson. 1946. Range vegetation studies. N Dak. Agr. Exp. Sta. Bull. 340. 43 p.

Whitman, W.C. 1953. Utilization of native grass in western North Dakota. N. Dak. Farm Res. 15:101-105.

Whitman, W.C., and E.I. Siggeirsson. 1954. Comparison of line interception and point contact methods in the analysis of mixed grass range vegetation. Ecology 35:431-436.

Whitman, W.C., D.R. Peterson, and T.J. Conlon. 1961. Results of clipping trials with cool season grasses. N. Dak. Agr. Exp. Sta. Rep. No. 588.6 p. 